УДК 681.62.067.35

\title{
ВИЗНАЧЕННЯ ЗАЛЕЖНОСТЕЙ ДЛЯ СИНТЕЗУ ЗАКОНІВ РУХУ ВИХІДНИХ ЛАНОК ОБЕРТОВИХ МЕХАНІЗМІВ ТАМПОДРУКАРСЬКИХ МАШИН
}

( О. О. Палюх, К.т.н., доцент, НТУУ «КПІ», Київ, Україна

Как показали проведенные исследования поворотных механизмов тампопечатных машин, сблокированных с разгружающими устройствами, пневматические нагружатели аккумулируют большую энергоемкость и при уравновешивания значительных избыточных сил обеспечивают высокую точность позиционирования.

As shown by studies of rotating mechanisms tampon printing machines, semi-detached from the unloading devices, air handlers accumulate more energy and balance the significant excess power for high positioning accuracy.

\section{Постановка проблеми}

Суттєве обмеження часу подачі виробу у зону друкування, на тамподрукарських машинах, до $20 \pm 30 \%$ від часу кінематичного циклу, а також необхідність забезпечення високої точності позиціювання, визначають необхідність дослідження вимог до динамічних характеристик транспортуючих механізмів, а також використання динамічно оптимальних законів руху та блокування цих механізмів з розвантажуючими пристроями для локалізації дії сил інерції.

\section{Аналіз попередніх}

\section{досліджень}

Відомо, що розвантажуючі пристрої зблоковані з виконавчими механізмами забезпечують розвантаження їх привода від передачі надлишкових навантажень. При цьому істотно зменшуються або повністю гасяться амплітуди збуджуваних коливань, підвищується рівномірність ходу, зменшується шум, підвищується точність позиціонування робочих органів.

Синтез виконавчих механізмів, як правило, розділяється на дві самостійні задачі: синтез закону руху вихідної ланки із умови повного розвантаження і синтез безпосередньо виконавчого механізму.

Синтез закону руху вихідної ланки за розвантажуючим пристроєм проводиться на базі рішення диференціального рівняння, що описує рух вихідної ланки за розвантажуючим пристроєм.

В залежності від типу розвантажуючого пристрою диференціальні рівняння руху можуть бути лінійними або нелінійними.

Для лінійних програмних розвантажувачів циклових механізмів (ПРЦМ), в яких маса вихідної ланки $(\mathrm{m})$ розташована між двох пружин стискання і рух цієї маси відповідає руху коливального 
контуру в консервативному полі, лінійне диференційне рівняння має вид

$$
\ddot{\mathrm{m}} \mathrm{s}+\mathrm{cs}=0
$$

де s - відхилення маси від положення статичної рівноваги; с $=\mathrm{F}_{\max } / 0,5 \mathrm{~s}-$ коефіцієнт жорсткості; $\mathrm{F}_{\max }-$ максимальне зусилля блоку пружин; s розмах руху маси.

\section{Мета роботи}

Дослідження та аналіз властивостей навантажувачів розвантажуючих пристроїв обертових механізмів тамподрукарських машин з врахуванням ряду факторів, основні із яких наступні: простота конструкції навантажувача, енергоємність, можливість зміни енергоємності, вплив на характеристики законів періодичної дії, синтезуючих по програмним розвантажувачам циклових механізмів (ПРЦМ).

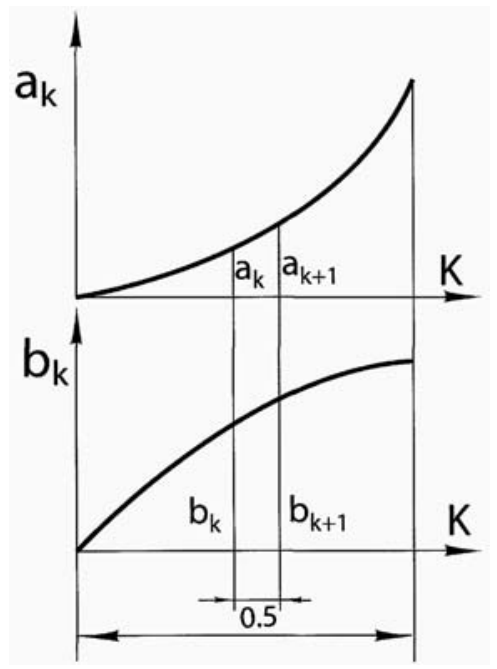

Рис. 1. Ділянка одиничних кінематичних діаграм

\section{Результати проведених досліджень}

У відповідності з одиничними діаграмами переміщення і швидкості вихідної ланки виконавчого механізму (рис. 1), можна записати для любої позиції

$$
\begin{aligned}
& \frac{b_{k}+b_{k+\Delta k}}{2} \Delta k= \\
& =a_{k+\Delta k}-a_{k},
\end{aligned}
$$

де $a_{k} i b_{k}-$ відповідно інваріанти переміщення і швидкості на попередній позиції i $a_{k+\Delta k}$ i $b_{k+\Delta k}$ - на наступній позиції.

Звідки інваріант переміщень для любої позиції буде дорівнювати

$$
\begin{aligned}
& a_{k+\Delta k}=a_{k}+ \\
& +\frac{1}{2}\left(b_{k}+b_{k+\Delta k}\right) \Delta k .
\end{aligned}
$$

Таким чином, за заданими дискретними значеннями інваріанта швидкості $b_{k}$ можна визначити значення інваріанта переміщення на відповідній позиції числовими методами.

Для цього використовуються енергосилові залежності розвантажуючого пристрою.

Поточне значення кінетичної енергії вихідної ланки виконавчого механізму дорівнює $0,5 \mathrm{l} \omega^{2}$.

Поточне значення потенціальної енергії, що віддається пневматичним розвантажуючим пристроєм дорівнює $\mathrm{F}\left(\mathrm{I}_{\mathrm{x} 1}-\mathrm{I}_{\mathrm{x} 2}\right)$, де $\mathrm{I}_{\mathrm{x} 1}$ i $\mathrm{I}_{\mathrm{x} 2}$ визначаються із трикутників $\mathrm{O}_{1} \mathrm{O}_{2} \mathrm{~A}_{1}$ і $\mathrm{O}_{1} \mathrm{O}_{2} \mathrm{~A}_{2}$ (рис. 2).

$$
\mathrm{I}_{\mathrm{x} 1}=\sqrt{\mathrm{a}^{2}+\mathrm{r}^{2}-2 \mathrm{a} \cdot \mathrm{r} \cdot \cos 0,5 \gamma_{\Sigma}}
$$

i $I_{x 2}=\sqrt{a^{2}+r^{2}-2 a \cdot r \cdot \cos 0,5\left(\gamma_{\Sigma}-\gamma\right)}$. 
Тоді вираз для потенціальної енергії буде мати вигляд

$$
\begin{aligned}
& \Pi=F\left[\sqrt{a^{2}+r^{2}-2 a \cdot r \cdot \cos 0,5 \gamma_{\Sigma}}-\right. \\
& \left.-\sqrt{a^{2}+r^{2}-2 a \cdot r \cdot \cos 0,5\left(\gamma_{\Sigma}-\gamma\right)}\right] .
\end{aligned}
$$

Або підставив геометричний параметр

$$
\begin{gathered}
\lambda=\frac{\mathrm{a}}{\mathrm{r}} \text { отримаємо } \\
\Pi=\operatorname{Fr}\left[\sqrt{\lambda^{2}+1-2 \cos 0,5 \gamma_{\Sigma}} .\right. \\
\left.-\sqrt{\lambda^{2}+1-2 \cos 0,5\left(\gamma_{\Sigma}-\gamma\right)}\right] .
\end{gathered}
$$

Із умови зрівноваження без врахування втрат на тертя слідує, що у кожній фазі кінематичного циклу потенціальна енергія, що віддається пневматичним циліндром і кінетична енергія, накопичувана вихідною ланкою, у кожній фазі кінематичного циклу повинні бути рівні

$$
\begin{aligned}
& \frac{1}{2} \mid \omega^{2}=\operatorname{Fr}\left[\sqrt{\lambda^{2}+1-2 \lambda \cos 0,5 \gamma_{\Sigma}}-\right. \\
& \left.-\sqrt{\lambda^{2}+1-2 \cos 0,5\left(\gamma_{\Sigma}-\gamma\right)}\right] .
\end{aligned}
$$

Підставив $\omega=\mathrm{b}_{\mathrm{k}} \frac{\gamma_{\Sigma}}{\mathrm{T}} \mathrm{i} \gamma=\mathrm{a}_{\mathrm{k} \gamma \Sigma}$, і вирішив відносно $b_{k}$ отримаєMO

$$
\begin{aligned}
& \mathrm{b}_{\mathrm{k}}=\sqrt{\frac{2 \mathrm{FrT^{2 }}}{\mathrm{l}_{\Sigma}{ }^{2}}}\left[\sqrt{\lambda^{2}+1-2 \lambda \cos 0,5 \gamma_{\Sigma}}-\right. \\
& -\left[\sqrt{\lambda^{2}+1-2 \cos \left(0,5 \gamma_{\Sigma}-\gamma\right)}\right] . \\
& \text { Позначивши } \mathrm{N}_{1}=\sqrt{\frac{2 F r T^{2}}{1 \gamma_{\Sigma^{2}}}} ; \\
& M=1+\lambda^{2} \mathrm{i} L=\sqrt{M-2 \lambda \cos 0,5 \gamma_{\Sigma}} .
\end{aligned}
$$

Приведемо до видів: для попередньої позиції k

$$
\begin{aligned}
& b_{k}=N_{1} \sqrt{L}- \\
& -\sqrt{M-2 \lambda \cos 0,5 \gamma_{\Sigma}\left(0,5-a_{k}\right)},
\end{aligned}
$$

для наступної позиції $\mathrm{k}+\Delta \mathrm{k}$

$$
\begin{aligned}
& b_{k+\Delta k}=N_{1} \sqrt{L}- \\
& -\sqrt{M-2 \lambda \cos 0,5 \gamma_{\Sigma}\left(0,5-a_{k+\Delta k}\right)} .
\end{aligned}
$$

Отримаємо вираз для позиційного інваріанта у вигляді зручному для подальшої обробки на комп'ютерній техніці

$$
\begin{aligned}
& a_{k+\Delta k}=a_{k}-\frac{N_{1}}{2}\left[\sqrt{L-\sqrt{M-2 \lambda \cos 0,5 \gamma_{\Sigma}\left(0,5-a_{k}\right)}}+\right. \\
& +\sqrt{L-\sqrt{\left.M-2 \lambda \cos 0,5 \gamma_{\Sigma}\left(0,5-a_{k+\Delta k}\right)\right] \Delta k}},
\end{aligned}
$$

$$
\Delta \mathrm{k}=\frac{1}{\mathrm{z}} \text { - крок розрахунку, }
$$

z - число позицій, визначене з умов необхідної точності обробки профілю кулачка.

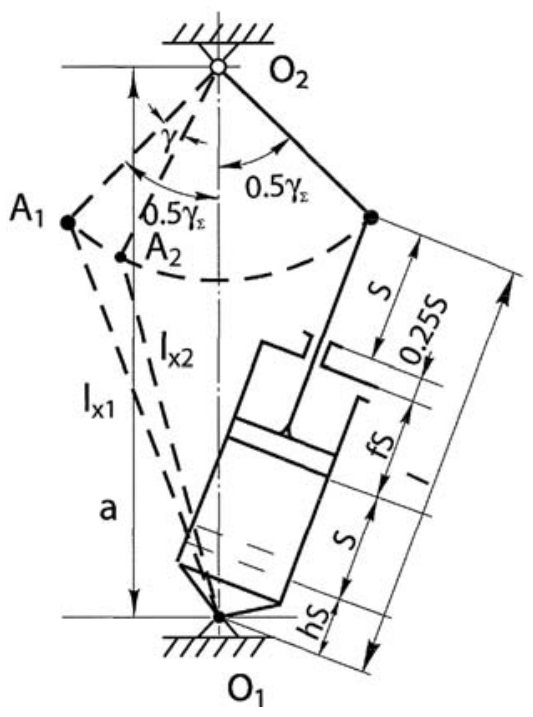

Рис. 2. Розрахункова схема розвантажуючого пристрою з пневмоциліндром 
Константа піка швидкості В відповідає положенню коромисла $\gamma=0,5_{\gamma \Sigma}$.

Після підстановки, отримаємо

$$
B=N_{1} \sqrt{(L-1+\lambda)} .
$$

Звідки

$$
\mathrm{N}_{1}=\frac{\mathrm{B}}{\sqrt{(L-1+\lambda)}} .
$$

Для визначення величини $\mathrm{N}_{1}$ у першому наближенні можна прийняти 1,57 (косінусоїдальний закон руху), тоді

$$
\mathrm{N}_{1}=\frac{1,57}{\sqrt{(L-1+\lambda)}}
$$

Послідовно вирішуючи рівняння (3.4), визначимо значення інваріантів переміщень при наближеному значенні $\mathrm{N}_{1}$.

Останнє отримане значення інваріанта при k = 0,5 повинно бути $\mathrm{a}_{\mathrm{k}(0,5)}=0,5$, якщо значення $\mathrm{N}_{1}$ вибране вдало. Якщо $\mathrm{a}_{\mathrm{k}(0,5)} \neq 0,5$, то слід ввести масштаб переходу до геометрично подібної одиничної діаграми переміщення

$$
y=\frac{0,5}{a_{k(0,5)}}
$$

і перераховувати раніше отримані інваріанти переміщення з врахуванням масштабу переходу $\mathrm{a}_{\mathrm{k}}=\mathrm{y} \mathrm{a}_{\mathrm{k}}$ і нове значення енергетичного параметра

$$
\mathrm{N}_{2}=\mathrm{yN}_{1} \text {. }
$$

\section{Висновки}

Як показали проведені дослідження, пневматичні навантажувачі являються більш складними і дорогими пристроями, так як для забезпечення їх високого ККД потрібне більш точне виконання елементів тертя та ущільнювачів.

Наряду з цим, пневматичні навантажувачі акумулюють більшу енергоємність і при зрівноваженні значних надлишкових сил їм, як правило віддається перевага.

У випадку використання розвантажуючих пристроїв в машинах із зміною робочих швидкостей, особливо при значному діапазоні змін, потрібно проводити налагодження енергоємності навантажувача, так як інерційні сили при цьому змінюються пропорційно квадрату швидкості.

Простота налагодження пневматичного навантажувача дозволяє змінювати його зусилля при пускових режимах роботи машини, що вигідно відрізняє пневматичний навантажувач від пружинного.

1. Билецкий А. А. Исследование устройств для уравновешивания избыточных нагрузок и выборки зазоров в кулачково-рычажных механізмах / Билецкий А. А. Автореф. дис. ... канд. техн. наук. - Львов, 1981. -20 с. 2. Вульфсон И. И. Динамические расчеты цикловых механизмов / И. И. Вульфсон. - Л. : Машиностроение, 1976. - 328 с. 3. Дитрих Я. Проектирование и конструирование. Системный поход / Я. Дитрих. - М. : Мир, 1981. - 456 с. 4. Котолюз Е. И. Уравновешивающие кулачковые механизмы с пневматическими нагружателями / Е. И. Котолюз, А. Н. Полюдов. Львов : УПИ им. И. Федорова, 1974. - 72 с. 5. Мордовин Б. М. Методы рас- 
чета цикличностей / Б. М. Мордовин. - Учеб. пос. - М. : МПИ, 1978. 6. Палюх А. А. Улучшение качественных характеристик поворотных кулачковых механизмов для привода транспортирующих устройств полиграфических машин / А. А. Палюх // В кн. : II Всесоюзная конференция молодых ученых и специалистов Госкомпечати СССР : Тез. докл. - Телави, 1990. 7. Палюх А. А. Параметрические исследования кулачковых поворотных механизмов / А. А. Палюх // В кн. : IX Всесоюзная научно-техническая конференция по специальным видам печати : Тез. докл. - Киев, 1990. 8. Палюх О. О. Механізми періодичного руху та рекомендації по їх застосуванню в поліграфічних машинах / А. А. Палюх. - Методичні вказівки. - Київ : НТуУ «КП।», 1995. - $52 \mathrm{c}$.

\section{Рецензент - В. В. Степанець,} к.т.н., доцент, НТУУ «КПІ»

Надійшла до редакції 29.08.11 